\title{
Perlindungan hukum tenaga kerja berdasarkan peraturan perundang- undangan di Indonesia
}

\author{
Ngabidin Nurcahyo
}

Ngabidin Nurcahyo; Program Magister Ilmu Hukum Universitas Merdeka Malang; Jl. Terusan Raya Dieng Nomor 62-64; Malang; 65146; Jawa Timur; Indonesia.

\begin{tabular}{l}
\hline A R T I C L E I N F O \\
\hline Article history: \\
Received 2020-12-22 \\
Received in revised form \\
2021-03-23 \\
Accepted 2021-04-01 \\
\hline
\end{tabular}

Kata kunci:

Jaminan Sosial; Pekerja; Pemberi

Kerja.

\section{Keywords:}

Social Security; Worker; Employer.

DOI: https://doi.org/10.26905/

idjch.v12i1.5781.

\section{How to cite item:}

Nurcahyo, N. (2021).

Perlindungan hukum tenaga

kerja berdasarkan peraturan perundang-undangan di Indonesia. Jurnal Cakrawala Hukum, 12(1), 69-78. doi:10.26905/idjch.v12i1.5781.

\begin{abstract}
Abstrak
Perlindungan tenaga kerja bagi pekerja sangatlah penting karena sesuai dengan pelaksanaan amanat Undang-Undang Dasar Tahun 1945, khususnya Pasal 27 Ayat (2) Tentang hak warga Negara atas pekerja dan penghidupan yang layak bagi kemanusiaan. Mengingat betapa pentingnya peran ketenagakerjaan bagi lembaga atau badan milik usaha Negara maupun swasta dalam upaya membatu tenaga kerja untuk memperoleh hak-haknya. Rumusan permasalahan dalam penulisan ini adalah bagaimanakah bentuk perlindungan hukum terhadap tenaga kerja berdasarkan Undang-Undang Nomor 24 Tahun 2011 tentang Badan Penyelenggara Jaminan Sosial (BPJS) dan bagaimanakah pertanggungjawaban dari pemberi kerja apabila ada tenaga kerja yang tidak terdaftar sebagai peserta BPJS. Hasil penelitian penulisan ini adalah perlindungan bagi pekerja dalam Undang-Undang BPJS adalah adanya kewajiban bagi pemberi kerja untuk mendaftarakan tenaga kerjanya ke dalam kepesertaan BPJS dan tanggung jawab pemberi kerja apabila tidak mendaftarkan kepesertaan BPJS adalah adanya sanksi mulai dari peringatan tertulis, denda, dan tidak dapat mendapatkan layanan publik tertentu.
\end{abstract}

\section{Abstract}

Labor protection for workers is very important because it is in accordance with the implementation of the mandate of the 1945 Constitution, particularly Article 27 Paragraph (2) concerning the rights of citizens to workers and a decent living for humanity. Given the important role of labor for state-owned and private institutions or enterprises in an effort to help workers to obtain their rights. The formulation of the problem in this writing is what is the form of legal protection for workers based on Law Number 24 of 2011 concerning the Social Security Administering Body (BPJS) and what is the responsibility of the employer if there are workers who

Corresponding Author:

* Ngabidin Nurcahyo.

E-mail address: welbecka@gmail.com. 


\section{Jurnal Cakrawala Hukum, Volume 12 No. 1 April 2021}

ISSN PRINT 2356-4962 ISSN ONLINE 2598-6538

are not registered as BPJS participants. The result of this research is that the protection for workers in the BPJS Law is that there is an obligation for employers to register their workforce into BPJS membership and the responsibility of employers if they do not register BPJS membership is that there are sanctions ranging from written warnings, fines, and cannot get certain public services.

\section{Latar Belakang}

Setiap tenaga kerja di berikan kesempatan untuk memperoleh kesempatan pekerjaan yang sesuai dengan kemampuan dan keahliannya serta diberikan upah/penghasilan yang layak sehingga dapat menjamin kesejahteraan dirinya beserta keluarga yang menjadi tanggungannya. Dengan demikan perlindungan kerja dapat dilakukan baik dengan jalan memberikan tuntunan, santunan maupun dengan jalan meningkatkan pengakuan hakhak asasi manusia, perlindungan fisik dan sosial ekonomi melalui norma yang berlaku dalam suatu perusahan (Sutedi, 2009).

Peningkatan perlindungan tenaga kerja adalah merupakan wahana yang harus diciptakan bagi setiap insan khususnya tenaga kerja baik yang melakukan pekerjaan dalam hubungan kerja langsung maupun tidak langsung. Uraian-uraian ini maka jaminan sosial tenaga kerja yang sekarang dikelola Badan Hukum Penyelenggara Jaminan Sosial (BPJS) akan berperan aktif sebagai perwujudan aspirasi perlindungan ketenaga kerjaan yang mempunyai dampak positif terhadap usaha-usaha peningkatan disiplin kerja dan peningkatan produktivitas tenaga kerja. Pemberi Kerja termasuk pemberi kerja, Pengurus Yayasan/Koperasi dan Usaha mandiri sebagaimana diatur dalam Pasal 15 Undang-Undang Nomor 24 Tahun 2011 tentang BPJS adalah wajib mendaftarkan dirinya dan pekerjanya di BPJS, di samping itu pemberi kerja wajib memperhatikan peningkatan kesejahteran tenaga kerja berdasarkan kemampuan dan kemajuan yang dicapai permberi kerja.
Jaminan Sosial Tenaga kerja ini awal mulanya merupakan suatu perwujudan dari Peraturan Pemerintah Nomor 33 Tahun 1997 yang dituangkan dalam Pasal 3, yang menyatakan bahwa "Perusahaan wajib menyelenggarakan program Asuransi Tenaga kerja baik dengan mempertanggungkan tenaga kerjanya yang bekerja dalam suatu ikatan kerja dengan perusahaan dalam program asuransi kecelakaan kerja dan asuransi kematian, maupun dengan memenuhi kewajibannya dalam program tabungan hari tua kepada badan penyelenggara' (Soepomo, 1992).

Menurut Undang-Undang Ketenagakerjaan pada Pasal 99 Ayat (1) dikatakan bahwa setiap pekerja/buruh dan keluarganya berhak memperoleh jaminan sosial tenaga kerja, kemudian Pasal 15 Ayat (1) Undang-Undang Nomor 24 Tahun 2011 Tentang Badan Penyelenggara Jaminan Sosial, yang menyebutkan "Pemberi kerja secara bertahap wajib mendaftarkan dirinya dan pekerjannya sebagai peserta kepada Badan Penyelenggara Jaminan Sosial sesuai dengan program jaminan sosial yang di ikuti".

Adanya perlindungan tenaga kerja adalah untuk memberikan perlindungan keselamatan bagi pekerja/buruh pada saat bekerja, sehingga apabila di kemudian hari terjadi kecelakaan kerja pekerja/ buruh tidak perlu khawatir karena sudah ada peraturan yang mengatur keselamatan bekerja dan tata cara penggantian ganti rugi dari kecelakaan kerja tersebut. Kecelakaan kerja adalah kecelakaan yang terjadi dalam hubungan kerja, termasuk kecelakaan yang terjadi dalam perjalanan dari rumah menuju tempat kerja atau sebaliknya dan penyakit 
yang disebabkan oleh lingkungan kerja. Kecelakaan kerja merupakan resiko yang harus dihadapi oleh tenaga kerja dalam melakukan pekerjaannya (Tim Visi Yustisia, 2014).

Upaya menanggulangi hilangnya sebagian atau seluruh penghasilan yang diakibatkan oleh adanya resiko-resiko sosial seperti sakit atau cacat karena kecelakaan kerja baik fisik maupun mental, maka diperlukan adanya jaminan kecelakaan kerja. Kesehatan dan keselamatan tenaga kerja merupakan tanggung jawab pemberi kerja sehingga pemberi kerja memiliki kewajiban untuk membayar iuran jaminan kecelakaan kerja yang berkisar antara $0,24 \% \mathrm{~s} / \mathrm{d} 1,74 \%$ sesuai kelompok jenis usaha. Menurut UU Ketenagakerjaan pada Pasal 99 Ayat (1) dikatakan bahwa setiap pekerja/buruh dan keluarganya berhak untuk memperoleh jaminan sosial tenaga kerja.

Ketentuan ini di pertegas kembali dalam pasal 3 ayat 1 Peraturan Pemerintah Republik Indonesia Nomor 86 Tahun 2013 tentang tata cara pengenaan Sanksi Administratif kepada pemberi kerja selain penyelenggara negara dan setiap orang, selain pemberi kerja, pekerja dan penerima bantuan iuran dalam penyelenggaraan Jaminan Sosial. Pemberi kerja selain penyelenggara Negara wajib: Mendaftarkan dirinya dan pekerjanya sebagai peserta kepada BPJS secara bertahap sesuai dengan program jaminan social yang diikuti; Memberikan data dirinya dan pekerjanya berikut anggota keluarganya kepada BPJS secara lengkap dan benar.

\section{Metode}

Jenis penelitian ini adalah penelitian yuridis normatif dimana akan diangkat adalah perlindungan hukum terhadap tenaga kerja berdasarkan Undang-Undang Republik Indonesia Nomor 24 Tahun 2011 tentang Badan Penyelenggara Jaminan Sosial (BPJS). Penelitian ini menitikberatkan kepada sumber bahan hukum berupa studi kepus- takaan yang didasarkan pada bahan hukum sekunder yang akan dikaitkan dengan keadilan sosial.

\section{Pembahasan}

\subsection{Perlindungan hukum terhadap tenaga kerja berdasarkan undang-undang nomor 24 tahun 2011 tentang Badan Penye- lenggara Jaminan Sosial}

Aspek perlindungan terhadap pekerja meliputi dua hal mendasar, yaitu perlindungan dari kekuasaan pemberi kerja dan perlindungan dari tindakan pemerintah. Perlindungan hukum dari kekuasaan pemberi kerja/majikan terlaksana apabila peraturan perundang-undangan dalam bidang perburuhan yang mengharuskan atau memaksa majikan bertindak seperti dalam perundangundangan tersebut benar-benar dilaksanakan semua pihak, karena keberlakuan hukum tidak dapat diukur secara yuridis saja, tetapi diukur secara sosiologis dan filosofis (Asikin, 2002).

Perlindungan pekerja secara tegas diatur berdasarkan Pasal 5 Undang-Undang Nomor 13 Tahun 2003 tentang Ketenagakerjaan. Pasal tersebut menyatakan bahwa setiap tenaga kerja berhak dan mempunyai kesempatan yang sama untuk memperoleh pekerjaan dan penghidupan yang layak tanpa membedakan jenis kelamin, suku, ras, agama, dan aliran politik sesuai dengan minat dan kemampuan tenaga kerja yang bersangkutan, termasuk perlakuan yang sama terhadap para penyandang cacat. Selanjutnya Pasal 6 mewajibkan kepada pemberi kerja untuk memberikan hak dan kewajiban pekerja/buruh tanpa membedakan jenis kelamin, suku, ras, agama, warna kulit, dan aliran politik.

Berdasarkan muatan pasal-pasal UU Ketenagakerjaan, maka lingkup perlindungan terhadap pekerja mencakup (Wahyudi, 2016): hak-hak dasar pekerja/buruh untuk berunding dengan pemberi kerja; keselamatan dan kesehatan kerja; Perlin- 
dungan khusus bagi pekerja/buruh perempuan, anak, dan penyandang cacat; dan Perlindungan tentang upah, kesejahteraan, dan jaminan sosial tenaga kerja.

Secara keseluruhan perlindungan pekerja/ buruh merupakan norma-norma hukum publik yang bertujuan untuk mengatur keadaan perburuhan di perusahaan. Juga termasuk seluruh norma hukum publik yang mempengaruhi dan mengancam, keamanan kesehatan kerja dan kesejahteraan buruh/pekerja dalam menjalankan pekerjaan. Lingkup pengaturan termaksud meliputi dua aspek yaitu: Aspek Materil, aspek ini secara umum meliputi keamanan kerja dan perawatan fisik; Aspek Immateril; Aspek immaterial meliputi waktu kerja dan peningkatan perkembangan jasmani dan fsikis pekerja.

Adapun Pemberian perlindungan hukum bagi pekerja menurut Imam Soepomo (2003), meliputi 5 bidang yaitu; Pengerahan/ penempatan tenaga kerja; Hubungan kerja; Kesehatan kerja; Keamanan kerja, dan Jaminan sosial buruh. Sementara dalam kesepatan lain Imam Soepomo mengelompokkan perlindungan kerja ke dalam 3 jenis perlindungan yaitu, Perlindungan ekonomis, perlindungan sosial dan perlindungan teknis.

Perlindungan Ekonomis terkadang disebut sebagai Jaminan Sosial yang merupakan perlindungan terhadap pekerja/buruh terkait penghasilannya. Perlindungan ini meliputi usaha-usaha yang dilakukan untuk memberikan penghasilan yang cukup bagi kebutuhan hidup pekerja beserta keluarganya (Asyhadie, 2007). Termasuk perlindungan pekerja bila bekerja diluar kehendaknya. Sehubungan dengan perlindungan terkait penghasilan, maka yang menjadi dasar permasalahannya adalah mengenai imbalan kerja yang didapatkan oleh pekerja yang diistilahkan dengan upah. Permasalahan upah merupakan persoalan klasik dalam bidang ketenagakerjaan dari masa kemasa. Sebab sulit mempertemukan 2 pihak yang masing masing mempunyai kepentingan yang berbeda. Oleh sebab itu dalam kerangka memberikan perlindungan secara ekonomis, maka kebutuhan terhadap aturan tentang pengupahan menjadi mutlak adanya.

Sebagaimana diketahui, bahwa secara ekonomi status pemberi kerja berada di atas pekerja, terlebih jika ditarik ke dalam lingkup perusahaan, maka yang terjadi adalah status atasan dan bawahan. Oleh sebab itu hubungan ini cendrung menempatkan para pekerja sebagai objek, atau dalam istilah buruh dianggap sebagai faktor ekstern yang berkedudukan sama dengan pelanggan pemasok atau pelanggan pembeli dan bukan faktor intern sebagai bagian yang tidak terpisahkan (Wijayanti, 2009).

Selain itu konsep ketenagakerjaan memasukkan "dengan menerima upah" sebagai salah satu unsur pengertiannya, yang juga diikuti dengan aturan-aturan tentang standar upah minimum (UMP, UMR). Dengan demikian pengabaian terhadap upah pekerja dapat dikategorikan sebagai pelanggaran berat, sebab hal ini berarti pelanggaran Hak Asasi Manusia (Budiastanti, E.D., Adnyana, I. and Agustine, A.D., 2020). Sementara itu, salah satu tanggung jawab dan kewajiban Negara untuk memberikan perlindungan sosial ekonomi kepada masyarakat termasuk pekerja diwujudkan dalam bentuk penyelenggaraan program jaminan sosial (Indrawati, I. and Simanjuntak, T.R., 2019).

Penyelenggaraan jamainan sosial ini di selengarakan oleh PT Jamsostek yang cakupannya tidak saja pada perlindungan secara ekonomi, namun termasuk juga perlindungan secara sosial/ kesehatan. Pada hakikatnya program jaminan soisal tenaga kerja dimaksud untuk memberikan kepastian berlangsungnya arus penerimaan penghasilan keluarga yang sebagian yang hilang. Disamping itu program jaminan sosial tenaga kerja mempunyai beberapa aspek antara lain: Memberikan perlindungan dasar untuk memenuhi kebutuhan hidup minimal bagi tenaga kerja beserta keluarganya; Merupakan penghargaan kepada te- 
naga kerja yang mendidik kemandirian pekerja sehingga pekerja tidak harus meminta belas kasihan orang lain jika dalam hubungan kerja terjadi resiko - resiko seperti kecelakaan kerja, sakit, hari tua dan lainnya.

Perlindungan keselamatan dan kesehatan terhadap tenaga kerja dimuat bersamaan dalam Pasal 86 ayat (1) Undang-Undang Nomor 13 Tahun 2003 tentang Ketenagakerjaan, disebutkan bahwa setiap pekerja/buruh mempunyai hak untuk memperoleh perlindungan atas keselamatan dan kesehatan kerja, moral, dan kesusilaan, serta perlakuan yang sesuai dengan harkat dan martabat manusia serta nilai-nilai agama. Adapun Kesehatan kerja didefinisikan sebagai setiap usaha dan upaya maupun aturan yang bertujuan untuk melindungi pekerja dari tindakan-tindakan maupun kondisi yang dapat mengganggu kesehatan fisik, psikis dan (melanggar norma) kesusilaan dalam suatu hubungan kerja (Uwiyono, 2014).

Kesehatan Kerja dimaksudkan sebagai perlindungan tenaga kerja dalam bentuk jaminan kesehatan kerja, dan kebebasan berserikat serta perlindungan hak untuk berorganisasi. Kesehatan kerja sebagaimana telah dikemukakan di atas termasuk jenis perlindungan sosial karena ketentuanketentuan mengenai kesehatan kerja ini berkaitan dengan sosial kemasyarakatan, yaitu aturan-aturan yang bermaksud mengadakan pembatasanpembatasan terhadap kekuasaan pemberi kerja untuk memperlakukan pekerja/buruh "semaunya" tanpa memperhatikan norma-norma yang berlaku, dengan tidak memandang pekerja/buruh sebagai mahluk Tuhan yang mempunyai hak asasi (Manullang, 2007).

Jaminan pemeliharaan kesehatan merupakan jaminan sebagai upaya penanggulangan dan pencegahan gangguan kesehatan yang memerlukan pemeriksaan, pengobatan, dan/atau perawatan termasuk kehamilan dan persalinan. Pemeliharaan kesehatan juga dimaksudkan untuk meningkatkan produktivitas tenaga kerja sehingga dapat melak- sanakan tugas sebaik-baiknya dan merupakan upaya kesehatan dibidang penyembuhan. Oleh karena upaya penyembuhan memerlukan dana yang tidak sedikit dan memberatkan jika dibebankan kepada perorangan, maka sudah selayaknya diupayakan penanggulangan kemampuan masyarakat melalui program jaminan social tenaga kerja.

Bahwa para pekerja dalam pembangunan nasional semakin meningkat, dengan resiko dan tanggung jawab serta tantangan yang dihadapinya. Oleh karena itu kepada mereka dirasakan perlu untuk diberikan perlindungan, pemeliharaan, dan peningkatan kesejahteraannya sehingga menimbulkan rasa aman dalam bekerja. Karena sifatnya yang hendak mengadakan "pembatasan" ketentuan-ketentuan perlindungan sosial dalam UU Ketenagakerjaan, Bab X Pasal 68 dan seterusnya bersifat "memaksa", bukan mengatur. Akibat adanya sifat memaksa dalam ketentuan perlindunga sosial UU No. 13 Tahun 2003 ini, pembentuk undangundang memandang perlu untuk menjelaskan bahwa ketentuan yang berkaitan dengan perlindungan sosial ini merupakan "hukum umum" (Publiekrechtelijk) dengan sanksi pidana. Hal ini disebabkan beberapa alasan berikut (Asyhadie, 2007): Aturan-aturan yang termuat di dalamnya bukan bermaksud melindungi kepentingan seorang saja, melainkan bersifat aturan bermasyarakat. Pekerja/buruh Indonesia umumnya belum mempunyai pengertian atau kemampuan untuk melindungi hak-haknya sendiri.

Kesehatan kerja bermaksud melindungi atau menjaga pekerja/buruh dari kejadian/keadaan hubungan kerja yang merugikan kesehatan dan kesusilaannya dalam hal pekerja/buruh melakukan pekerjaannya. Adanya penekanan "dalam suatu hubungan kerja" menunjukkan bahwa semua tenaga kerja yang tidak melakukan hubungan kerja dengan pemberi kerja tidak mendapatkan perlindungan sosial sebagaimana ditentukan dalam Bab X UU Ketenagakerjaan. Dengan demikian, tujuan peraturan keselamatan dan kesehatan kerja 
adalah: Melindungi pekerja dari resiko kecelakaan kerja; Meningkatkan derajat kesehatan para pekerja/buruh; Agar pekerja/buruh dan orang-orang di sekitarnya terjamin keselamatannya; Menjaga agar sumber produksi dipelihara dan dipergunakan secara aman dan berdaya guna.

Keselamatan dan kesehatan kerja harus diterapkan dan dilaksanakan di setiap tempat kerja. Unsur tempat kerja ada 3 (tiga), yaitu: Adanya suatu usaha, baik bersifat ekonomis maupun sosial; Adanya sumber bahaya; Adanya tenaga kerja yang bekerja di dalamnya, baik terus-menerus maupun sewaktu-waktu.

Keselamatan kerja didefinisikan sebagai segala aturan dan upaya yang bertujuan untuk menyediakan perlindungan teknis bagi pekerja dari resiko kerja terkait penggunaan alat/mesin, material (bahan berbahaya/beracun), jenis kerja, lokasi, waktu, dan kondisi tempat kerja selama masa kerja berlangsung.

Termasuk ke dalam perlindungan ini adalah ketersediaan sarana dan prasarana penunjang sebagai langkah antisipasi jika terjadi kecelakaan kerja. Kecelakaan Kerja sebagai yang dijelaskan berdasarkan UU Nomor 1 Tahun 1970 tentang Keselamatan Kerja, adalah suatu kejadian yang tidak diduga semula dan tidak dikehendaki, yang mengacaukan proses yang telah diatur dari suatu aktivitas dan dapat menimbulkan kerugian baik korban manusia maupun harta benda. Sedangkan menurut UU No. 3 Tahun 1992 tentang Jamsostek, "Kecelakaan kerja adalah kecelakaan yang terjadi berhubung dengan hubungan kerja, termasuk penyakit yang timbul karena hubungan kerja, demikian pula kecelakaan yang terjadi dalam perjalanan berangkat dari rumah menuju tempat kerja, dan pulang ke rumah melalui jalan yang biasa atau wajar dilalui.

Berdasarkan pengertian tersebut di atas, maka cakupan perlindungan teknis sangat luas, sebab erat kaitannya dengan pencegahan terjadinya kecelakaan kerja, sementara jangkauan pengertian kecelakan kerja memasukkan segala hal yang timbul dan terjadi selama seorang pekerja berada dalam hubungan kerja termasuk pulangperginya seorang pekerja dari/ke tempat kerja. Tujuan utama dari bentuk perlindungan ini adalah terwujudnya keselamatan sepanjang hubungan kerja, yang selanjutnya akan menciptakan perasaan aman dan nyaman bagi para pekerja untuk melaksanakan tugas/kerjanya secara optimal, tanpa perlu merasa takut maupun khawatir akan terjadinya kecelakaan. Kalaupun terlanjur terjadi, penanganannya dapat segera dilakukan.

Berbeda dengan perlindungan kerja lain yang umumnya ditentukan untuk kepentingan pekerja/buruh saja, keselamatan kerja ini tidak hanya memberikan perlindungan kepada pekerja/ buruh, tetapi kepada pemberi kerja dan pemerintah. Bagi pekerja/buruh, adanya jaminan perlindungan keselamatan kerja akan menimbulkan suasana kerja yang tentram sehingga pekerja/ buruh dapat memusatkan perhatian pada pekerjaannya semaksimal mungkin tanpa khawatir sewaktu-waktu akan tertimpa kecelakaan kerja. Bagi pemberi kerja, adanya pengaturan keselamatan kerja di dalam perusahaannya akan dapat mengurangi terjadinya kecelakaan yang dapat mengakibatkan pemberi kerja harus memberikan jaminan sosial. Bagi pemerintah (dan masyarakat), dengan adanya dan ditaatinya peraturan keselamatan kerja, maka apa yang direncanakan pemerintah untuk mensejahterakan masyrakat akan tercapai dengan meningkatnya produksi perusahaan baik kualitas maupun kuantitas.

\subsection{Pertanggungjawaban dari pemberi kerja apabila ada tenaga kerja yang tidak ter- daftar sebagai peserta BPJS.}

Berdasarkan ketentuan Pasal 100 Undangundang Ketenagakerjaan, yaitu meningkatkan kesejahteraan bagi pekerja/buruh dan keluarganya, pemberi kerja wajib menyediakan fasilitas 
kesejahteraan. Penyediaan fasilitas kesejahteraan sebagaimana yang dimaksud dalam ayat (1), dilaksanakan dengan memperhatikan kebutuhan pekerja/buruh dan ukuran kemampuan perusahaan. Ketentuan mengenai jenis dan kriteria fasilitas kesejahteraan sesuai dengan kebutuhan pekerja/ buruh dan ukuran kemampuan perusahaan sebagaimana dimaksud dalam ayat (1) dan (2), diatur dengan Peraturan Pemeriantah (Wijayanti, 2009).

Perlindungan, pemeliharaan, dan peningkatan kesejahteraan yang berbentuk Program Jaminan Tenaga Kerja yang dicanangkan oleh pemerintah dan wajib dilaksanakan oleh pemberi kerja, apabila di dalam pelaksanaannya telah memenuhi persyaratan yang ditentukan, yaitu mempunyai pekerja sebanyak 10 (sepuluh) orang atau lebih dan juga mengeluarkan uang untuk menggaji pekerjanya sebesar 1 (satu) juta rupiah untuk setiap bulannya.

Jaminan sosial tenaga kerja sebagaimana dimaksud dalam Pasal 6 diperuntukan bagi tenaga kerja. Tenaga kerja yang melakukan pekerjaan, setiap saat menghadapi resiko sosial berupa peristiwa yang dapat mengakibatkan berkurangnya atau hilangnya pengahasilan. Oleh karena itu, perlu adanya peningkatan perlindungan tenaga kerja oleh pemberi kerja yang bertujuan untuk memberikan ketenagan bekerja dan menjamin kesejahteraan tenaga kerja beserta keluarganya.

Dalam hubungan kerja, hak dan kewajiban para pihak saling bertimbal balik, hal-hal yang menjadi hak pekerja merupakan kewajiban pemberi kerja untuk dipenuhi, sabaliknya hal-hal yang menjadi hak pemberi kerja adalah merupakan kewajiban pemberi kerja.

Pada umumnya yang menjadi kewajiban pemberi kerja/pemberi kerja ketentaunnya diatur dalam kaidah heteronom yang dibuat oleh pemerintah dalam rangka melindungi pekerja di perusahaan. Apabila ingin diatur lebih khusus terkait perusahaan tempat pekerja melakukan pekerjaan, maka ketentuannya biasanya diatur dalam kaidah otonom, yaitu melaui perundingan untuk menyusun perjanjian kerja bersama atau diatur tersendiri di dalam peraturan perusahaan.

Bertolak dari substansi/unsur perjanjian kerja sebagai awal hubungan kerja, maka yang menjadi kewajiban pemberi kerja/pemberi kerja adalah: menyediakan pekerjaan yang akan dilakukan pekerja dan membayar upah atau imbalan atas pekerjaan yang dilakukan pekerja/buruh. Disisi lain, pekerja/buruh berhak untuk melakukan pekerjaan sesuai perjanjian yang diadakan dan memperoleh imbalan atau upah atas pekerjaan yang dilakukan. Menjadi kewajiban pekerja/buruh dalam hal tersebut adalah melakukan pekerjaan dengan sebaik-baiknya atas petunjuk atau perintah yang diberikan oleh pemberi kerja/pemberi kerja, sesuai waktu yang ditentukan.

Sistem Jaminan Sosial Nasional (SJSN), khususnya Jaminan Kesehatan di Indonesia memasuki era baru dengan diundangkannya Undang-Undang Nomor 24 Tahun 2011 tentang Badan Penyelenggara Jaminan Sosial (BPJS) yang ditindak lanjuti dengan Peraturan Presiden Nomor 12 Tahun 2013 tentang Jaminan Kesehatan sebagaimana diubah dengan Peraturan Presiden Nomor 28 tahun 2016 tentang Perubahan Atas Peraturan Presiden Nomor 12 tahun 2013 tentang Jaminan Kesehatan.

Pasal 11 ayat (5) Peraturan Presiden Nomor 28 tahun 2016 tentang Jaminan Kesehatan menyebut jika pekerja/buruh belum terdaftar pada BPJS Kesehatan, pemberi kerja wajib bertanggung jawab pada saat pekerja membutuhkan pelayanan kesehatan sesuai manfaat yang diberikan oleh BPJS Kesehatan. Pasal 11 ayat (6) mengatur sanksi untuk pemberi kerja yang belum mendaftarkan pekerjanya dalam program JKN, sanksi berupa teguran tertulis; denda; dan/atau tidak mendapat pelayanan publik tertentu.

Pemeliharaan kesehatan untuk meningkatkan produktifitas tenaga kerja sehingga dapat melaksanakan tugas dengan sebaik-baiknya. Program pemeliharaan kesehatan ini merupakan 
upaya penanggulangan dan pencegahan gangguan kesehatan yang memerlukan pemeriksaan, pengobatan dan atau perawatan termasuk kehamilan dan persalinan. Jaminan ini meliputi upaya peningkatan kesehatan (Promotif) dan pemulihan (Rehabilitatif). Manfaat Jaminan Pemeliharaan Kesehatan bagi perusahaan yakni perusahaan dapat memiliki tenaga kerja yang sehat, dapat konsentrasi dalam bekerja sehingga lebih produktif.

Jaminan kecelakaan kerja diatur dalam Undang-Undang Nomor 40 Tahun 2004 tentang Sistem Jaminan Sosial Nasional (UU SJSN) dan diselenggarakan dengan tujuan menjamin agar peserta memperoleh manfaat pelayanan kesehatan dan santunan uang tunai apabila pekerja mengalami kecelakaan kerja atau menderita penyakit akibat kerja. Adanya Undang-Undang Nomor 24 Tahun 2011 tentang Badan Penyelenggara Jaminan Sosial (BPJS) merupakan tujuan dari undangundang nomor 40 tahun 2004 tentang Sistem Jaminan Sosial Nasional. Jaminan kecelakaan secara khusus diatur dalam Peraturan Pemerintah Nomor 44 Tahun 2015 tentang Penyelenggaraan Program Jaminan Kecelakaan Kerja dan Jaminan Kematian.

Jaminan kecelakaan kerja (JKK) memberikan kompensasi dan rehabilitasi bagi tenaga kerja yang mengalami kecelakaan pada saat mulai berangkat bekerja sampai tiba kembali dirumah atau menderita penyakit akibat hubungan kerja (Manulang, 2001).

Dari ketentuan itu dapat dijabarkan bahwa ruang lingkup jaminan kecelakaan kerja meliputi kecelakaan dan sakit akibat kerja. Kecelakaan kerja apabila mengalami kecelakaan pada saat perjalanan menuju tempat kerja, di tempat kerja, atau perjalanan dari tempat kerja. Sakit akibat kerja apabila timbulnya penyakit setelah pekerja mnjalankan pekerjaan relatif dalam dalam jangka waktu yang lama. Dalam bekerja Keselamatan dan kesehatan kerja (K3) merupakan faktor yang sangat penting untuk diperhatikan karena seseorang yang meng- alami sakit atau kecelakaan dalam bekerja akan berdampak pada diri, keluarga dan lingkungannya. Salah satu komponen yang dapat meminimalisir kecelakaan dalam kerja adalah tenaga kesehatan. Tenaga kesehatan mempunyai kemampuan untuk menangani korban dalam kecelakaan kerja dan dapat memberikan penyuluhan kepada masyarakat untuk menyadari pentingnya keselamatan dan kesehatan kerja (Sunyoto, 2013).

Tujuan keselamatan kerja adalah melindungi tenaga kerja atas keselamatannya dalam melaksanakan pekerjaannya untuk kesejahteraan hidup, meningkatkan produksi serta produktifitas nasional, menjamin keselamatan setiap pekerja/buruh dan melindungi sumber produksi agar dipelihara dan dipergunakan secara aman dan efisien. Pemberi kerja tetap berkewajiban mengadakan pemeliharaan kesehatan kerja yang meliputi upaya peningkatan (promotif), pencegahan (preventif) penyembuhan (kuratif), dan pemulihan (rehabilitatif). Dengan demikian, diharapkan tercapainya derajat kesehatan pekerja yang optimal sebagai potensi yang produktif bagi pembangunan. Jaminan pemeliharaan kesehatan selain untuk pekerja yang bersangkutan juga untuk keluarganya. Jaminan pemeliharaan kesehatan yang diberikan kepada tenaga kerja adalah untuk meningkatkan produktivitas, sehingga dapat melaksanakan sebaik-baiknya dan merupakan upaya kesehatan di bidang pengembangan.

Pemberian pelayanan kesehatan yang dijamin dalam Peraturan Presiden Nomor 19 Tahun 2016 Tentang Perubahan Atas Peraturan Presiden Nomor 12 Tahun 2013 (Pasal 22) adalah sebagai berikut: Pelayanan kesehatan tingkat pertama; Pelayanan tingkat rujukan tingkat lanjutan; Pelayanan kesehatan lain yang ditetapkan oleh Menteri. Secara garis besar ada tiga metode pelayanan medis dalam pelaksanaan jaminan pemeliharaan kesehatan, yaitu metode restitusi terbatas, metode pelayanan medis secara langsung, dan metode pembayaran kepada tenaga medis. 
Kecelakaan kerja maupun penyakit akibat kerja merupakan risiko yang dihadapi oleh tenaga kerja yang melakukan pekerjaan. Untuk menanggulangi hilangnya sebagian atau seluruh penghasilannya yang diakibatkan oleh kematian atau cacat karena kecelakaan kerja, baik fisik maupun mental maka perlu adanya jaminan kecelakaan kerja. Mengingat gangguan mental akibat kecelakaan kerja sifatnya sangat relatif, sehingga sulit ditetapkan derajat cacatnya, maka jaminan atau santunan hanya diberikan dalam hal terjadi cacat mental tetap yang mengakibatkan pekerja yang bersangkutan tidak bisa bekerja lagi (Asyhadie, 2013).

Santunan kecelakaan kerja adalah santunan yang diberikan kepada tenaga kerja yang mengalami kecelakaan kerja. Santunan berupa uang akan diberikan kepada tenaga kerja atau keluarganya. Pembayaran santunan ini prinsipnya diberikan secara berkala dengan maksud agar tenaga kerja atau keluarganya dapat memenuhi sebagian dari kebutuhan hidupnya secara terus-menerus. Selain itu pembayaran santunan secara berkala dapat juga diberikan secara sekaligus. Hal ini dimaksudkan untuk mendorong ke arah kegiatan yang bersifat produktif dalam meningkatkan kesejahteraannya.

Pentingnya tanggung jawab pemberi kerja terhadap jaminan sosial terhadap pekerjanya diatur di dalam Pasal 15 ayat (1) UU BPJS dimana dikatakan bahwa pemberi kerja secara bertahap wajib mendaftarkan dirinya dan pekerjanya sebagai peserta kepada BPJS sesuai dengan Program Jaminan Sosial yang diikuti. Mengingat pentingnya keikutsertaan pekerja dalam jaminan sosial, di dalam Pasal 3 ayat (1) Peraturan Pemerintah Nomor 86 Tahun 2013 tentang Tata Cara Pengenaan Sanksi Administratif Kepada Pemberi Kerja selain penyelenggara negara dan setiap orang, selain pemberi kerja, pekerja, dan penerima bantuan iuran dalam penyelenggaraan jaminan sosial (yang selanjutnya disebut dengan PP 86/2013) “Pemberi Kerja Selain Penyelenggara Negara wajib: mendaftarkan diri- nya dan pekerjanya sebagai peserta kepada BPJS secara bertahap sesuai dengan program jaminan sosial yang diikutinya; dan memberikan data dirinya dan pekerjanya berikut anggota keluarganya kepada BPJS secara lengkap dan benar.

Adapun sanksi jika perusahaan selain penyelenggara negara tidak melaksanakan kewajiban mendaftarkan pekerjanya sebagai Peserta kepada BPJS adalah sanksi administratif, Sanksi administratif itu dapat berupa: teguran tertulis yang akan dilakukan oleh BPJS; denda; dan/atau yang dilakukan oleh BPJS; tidak mendapat pelayanan publik tertentu. Yang akan dilakukan oleh Pemerintah atau pemerintah daerah atas permintaan BPJS.

\section{Simpulan}

Pemerintah melalui berbagai Undangundang dan peraturan pelaksanaannya, di samping memberikan penegasan terhadap wujud hak-hak yang dimiliki oleh pekerja, juga menyertakan jaminan-jaminan perlindungan terhadap hak-hak pekerja tersebut. Secara umum bentuk perlindungan yang terkait dengan hal tersebut di atas adalah, terbitnya berbagai peraturan yang mengatur tentang upah, jam kerja, cuti/libur, kesehatan dan keselamatan kerja, organisasi pekerja/buruh dan lainlain. Di samping itu diselenggarakan pula dalam bentuk program-program jaminan sosial bidang ketenagakerjaan, yang meliputi jaminan sosial dan kesehatan sebagaimana diatur di dalam Undang-Undang Nomor 24 Tahun 2011 tentang Badan Penyelenggara Jaminan Sosial (BPJS)

Keselamatan kerja merupakan salah satu upaya untuk menciptakan tempat kerja yang aman, sehingga dapat mengurangi dan/atau bebas dari kecelakaan kerja yang pada akhirnya dapat meningkatkan efisiensi dan produktivitas pekerja/ buruh. Oleh karena itu, penting bagi pemberi kerja untuk menerapkan jaminan kecelakaan kerja. Jaminan kecelakaan kerja memberikan kompensasi dan rehabilitasi bagi tenaga kerja yang mengalami 


\section{Jurnal Cakrawala Hukum, Volume 12 No. 1 April 2021}

ISSN PRINT 2356-4962 ISSN ONLINE 2598-6538

kecelakaan pada saat mulai berangkat bekerja sampai tiba kembali dirumah atau menderita penyakit akibat hubungan kerja. Terkait sanksi, apabila pemberi kerja yang tidak mengikutsertakan pekerja/buruh dalam program BPJS maka terdapat sanksi mulai dari peringatan tertulis, denda, dan tidak dapat mendapatkan layanan publiK tertentu.

\section{DaftarPustaka}

Agusmindah. 2010. Hukum Ketenagakerjaan Indonesia, Dinamika E Kajian Teori. Ghalia Indonesia. Jakarta.

Alrasjid, Harun. 1978. Program Jaminan Sosial Sebagai Salah Satu Usaha Penanggulangan Masalah Kemiskinan di Indonesia. Pustaka. Jakarta.

Asikin, Zainal., dkk. 2002. Dasar-Dasar Hukum Perburuhan. cet. 4. Raja Grafindo Persada. Jakarta.

Asyhadie, Lih. Zaeni. 2007. Hukum Kerja. RajaGrafindo Persada. Jakarta.

Asyhadie, Zaeni. 2007. Hukum Kerja: Hukum Ketenagakerjaan Bidang Hubungan Kerja. Rajagrafindo Persada. Jakarta.

Budiastanti, E.D., Adnyana, I. and Agustine, A.D., 2020. Aspek yuridis program e-karir dalam perspektif hukum ketenagakerjaan. Jurnal Cakrawala Hukum, 11(2), pp.147-156.

Hadjon, Philipus M. 1983. Perlindungan Hukum Bagi Masyarakat Indonesia. Bina Ilmu. Surabaya.

Indrawati, I. and Simanjuntak, T.R., 2019. Pertanggungjawaban Pidana Terhadap Perusahaan yang Lalai Mendaftarkan Pekerjanya Sebagai Peserta BPJS Ketenagakerjaan. Jurnal Cakrawala Hukum, 10(1), pp.50-57.

Manulang, Sendjun. 2001. Pokok-pokok Hukum Ketenagakerjaan Indonesia. Rineka. Jakarta.

Manullang, E. F. M. 2007. Menggapai Hukum Berkeadilan Tinjauan Hukum Kodrat dan Antinomi Nilai. Kompas Media Nusantara. Jakarta.

Peraturan Pemerintah Republik Indonesia Nomor 109 Tahun 2013 tentang Penahapan Kepesertaan Program Jaminan Sosial.
Peraturan Pemerintah Republik Indonesia Nomor 14 tahun 1993 tentang Penyelenggaran Program Jaminan Sosial Tenaga Kerja dan perubahannya yang ketujuh dengan Peraturan Pemerintah Nomor 84 Tahun 2013.

Peraturan Pemerintah Republik Indonesia Nomor 44 Tahun 2015 tentang Penyelenggaraan Program Jaminan Kecelakaan Kerja dan Jaminan Kematian.

Peraturan Pemerintah Republik Indonesia Nomor 45 Tahun 2015 tentang Penyelenggaraan Program Jaminan Pensiun.

Peraturan Pemerintah Republik Indonesia Nomor 46 Tahun 2015 tentang Penyelenggaraan Program Jaminan Hari Tua.

Peraturan Pemerintah Republik Indonesia Nomor 85 Tahun 2013 tentang Tata Cara Hubungan Antar Lembaga BPJS.

Peraturan Pemerintah Republik Indonesia Nomor 86 Tahun 2013 tentang Tata Cara Pengenaan Sanksi Administratif Kepada Pemberi Kerja selain Penyelenggara Negara dan setiap orang, selain Pemberi Kerja, Pekerja \& Penerima Bantuan Iuran dalam Penyelenggara Jaminan Sosial.

Soepomo, Imam. 2003. Pengantar Hukum Perburuhan. Djambatan. Jakarta.

Sunyoto, Danang. 2013. Hak dan Kewajiban Bagi Pekerja dan Pemberi kerja. Pustaka Yustita. Jakarta.

Sutedi, Adrian. 2009. Hukum Perburuhan. Sinar Grafika. Jakarta.

Toha, Halili \& Pramono, Hariri 1987. Hubungan Kerja Antara Majikan dan Buruh. Bina Aksara. Jakarta.

Undang-Undang Republik Indonesia Nomor 24 Tahun 2011 tentang Badan Penyelenggara Jaminan Sosial.

Undang-Undang Republik Indonesia Nomor 40 Tahun 2004 tentang Sistem Jaminan Sosial.

Uwiyono, Aloysius., dkk. 2014. Asas-asas Hukum Perburuhan. Rajagrafindo Persada. Jakarta.

Uwiyono, Aloysius., dkk. 2014. Asas-asas Hukum Perburuhan. Rajawali Pers. Jakarta.

Wahyudi, Eko., et. Al., 2016. Hukum Ketenagakerjaan. Sinar Grafika. Jakarta.

Wijayanti, Asri. 2009. Hukum Ketenagakerjaan Pasca Reformasi. Sinar Grafika. Jakarta. 